\title{
Synthesis and Properties of Poly(methacrylate) Bearing a Phosphorylcholine Analogous Group
}

\author{
Tsutomu Oishi, ${ }^{\dagger}$ Hironobu UchiYama, Kenjiro Onimura, \\ and Hiromori TsuTsumi \\ Department of Applied Chemistry and Chemical Engineering Yamaguchi University, \\ 2557 Tokiwadai, Ube, Yamaguchi 755, Japan
}

(Received April 25, 1997)

\begin{abstract}
A novel type of methacrylate bearing a phosphorylcholine analogous group, 2-[3'-(trimethylammonium)propylphosphoryl] ethyl methacrylate (TPM) was synthesized. TPM was polymerized and copolymerized with vinyl monomers in the presence of radical initiators. Monomer reactivity ratios and $Q$ and $e$ for TPM were determined. A critical micelle concentration (CMC) of TPM was $3.6 \times 10^{-3} \mathrm{moll}^{-1}$. Two types of copolymer microspheres of methyl methacrylate (MMA) with TPM or 2-methacryloyloxyethyl phosphorylcholine (MPC) were prepared from emulsifier-free emulsion copolymerizations over the CMC. The suppression of bovine serum albumin (BSA) adsorption onto poly(TPM-co-MMA) microsphere was similar to that onto the poly(MPC-co-MMA). The length of three methylene units between zwitter-ions in the phosphorylcholine group could not prevent depressing BSA adsorption.
\end{abstract}

KEY WORDS Phosphorylcholine / Methacrylate / Polymer Microsphere / Adsorption of albumin /

A biomembrane mainly consists of phospholipids and lecithin [Scheme 1, A] containing a phosphorylcholine moiety. Synthetic polymers containing a phosphatidylcholine moiety have been extensively studied from several viewpoints of polymer chemistry, biological, medical and life science. ${ }^{1-15}$ Lately polymers obtained from a vinyl monomer, 2-methacryloyloxyethyl phosphorylcholine (MPC) [Scheme 1, B] are particularly interesting. Nakabayashi, Ishihara and co-workers reported that MPC copolymers with $n$-butyl methacrylate (BMA) possess outstanding blood compatibility, i.e., suppression of protein adsorption and platelet adhesion. ${ }^{16-21}$ Sugiyama et al. reported that microspheres composed of MPC and alkyl methacrylate decrease bovine serum albumin (BSA) adsorption compared with poly(methyl methacrylate) (PMMA) microspheres. That is, the introduction of a very small amount of MPC moiety (even at lower than $0.05 \mathrm{~mol} \%$ in feed) onto PMMA microspheres results in drastic reduction in BSA adsorption. ${ }^{22,23}$ More recently, they reported that copolymer microspheres composed of 2-acryloyloxyethyl phosphorylcholine (APC) [Scheme 1, C] with alkyl methacrylate superior to the MPC copolymer microspheres with respect to suppression of protein adsorption. ${ }^{24}$ Other groups report that fibrinogen adsorption and platelet adhesion are reduced on the poly(MPC-coBMA) and poly(MPC-co-n-dodecyl methacrylate). ${ }^{25}$ These results strongly suggest that the introduction of phosphorylcholine groups into a polymer surface is useful for improvement of protein adsorption-resistance properties.

We also reported the synthesis and brief study on biocompatibility of poly(fumaramate) bearing a phosphorylcholine moiety. ${ }^{26}$ Microspheres composed of the fumaramate with methyl methacrylate (MMA) reduced BSA adsorption as well as microspheres composed of MPC with MMA. This suggests that the structure of the rigid polymer main chain bearing an amide group at the side chain is not concerned with BSA adsorption.

There is no doubt of the excellent biocompatibility of a phosphorylcholine moiety. We added a methylene to an ethylene unit in the phosphorylcholine group and synthesized a novel type of methacrylate bearing a phosphorylcholine analogous group, 2-[3'-(trimethylammonium)propylphosphoryl]ethyl methacrylate (TPM) [Scheme 1, D].

The present paper describes the synthesis of TPM, polymerizability and emulsifier free emulsion copolymerizations of MMA with TPM. The poly(TPM-co-MMA) microspheres obtained were characterized, and adsorption behavior of BSA was investigated, and compared with poly(MPC-co-MMA) microspheres.

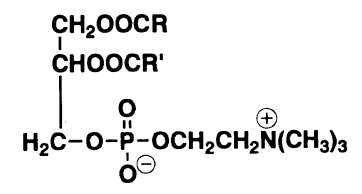

(A)

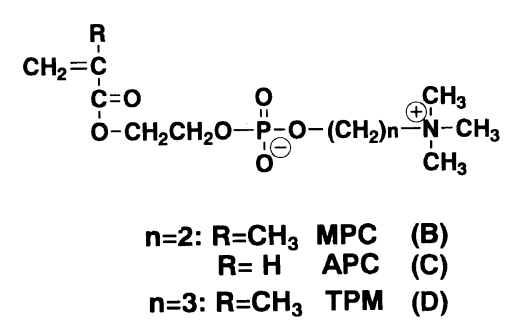

Scheme 1.

\section{EXPERIMENTAL}

\section{TPM Monomer}

TPM monomer was synthesized from 2-hydroxyethyl methacrylate (HEMA), 2-chloro-2-oxo-1,3,2-dioxaphosphorinane (CODPR), and trimethylamine, as illustrated

\footnotetext{
${ }^{\dagger}$ To whom all correspondence should be addressed. (Tel \& Fax: +81-836-35-9427, e-mail: oishi@po.cc.yamaguchi-u.ac.jp).
} 


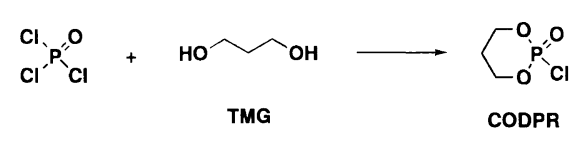
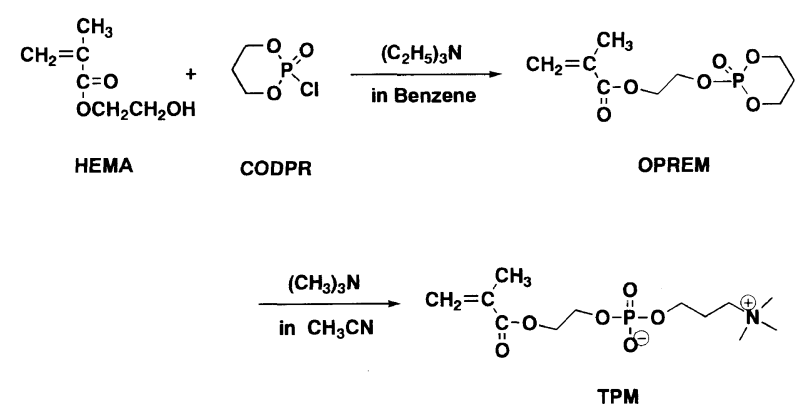

Scheme 2. Synthetic scheme for TPM.

in Scheme 2.

\section{Preparation of TPM}

2-Chloro-2-oxo-1,3,2-dioxaphosphorinane (CODPR). CODPR was synthesized according to the method of Lanham et al. ${ }^{27}$ and purified by distillation under reduced pressure, bp $113^{\circ} \mathrm{C} / 4.0 \times 10^{-2} \mathrm{mmHg}, \mathrm{mp} 39^{\circ} \mathrm{C}$ (lit. ${ }^{27} \mathrm{mp} 39^{\circ} \mathrm{C}$ ). ${ }^{13} \mathrm{C}$ NMR ( $\delta$ in ppm from tetramethylsilane (TMS) in $\left.\mathrm{CDCl}_{3}\right)$ : $70.33\left(-\mathrm{OCH}_{2} \mathrm{CH}_{2} \mathrm{CH}_{2} \mathrm{O}-\right)$, $25.65\left(-\mathrm{OCH}_{2} \mathrm{CH}_{2} \mathrm{CH}_{2} \mathrm{O}-\right)$.

2-(2-Oxo-1,3,2-dioxaphosphorinane-2-yloxy)ethyl Methacrylate (OPREM). HEMA $(7.5 \mathrm{~g}, 0.058 \mathrm{~mol})$, triethylamine (TEA; $5.0 \mathrm{~g}, 0.058 \mathrm{~mol})$, and benzene $(120 \mathrm{ml})$ were placed in a $300 \mathrm{ml}$ round bottom flask. After the solution was heated at $60^{\circ} \mathrm{C}$ with a water bath, $9.0 \mathrm{~g}$ of CODPR in $70 \mathrm{ml}$ of benzene were added to the stirred solution. After being kept at $60^{\circ} \mathrm{C}$ for 2.5 days, the precipitate (triethylammonium chloride) was filtered off. The filtrate was extracted with water and evaporated under reduced pressure. OPREM was obtained as a colorless liquid. Yield $10.6 \mathrm{~g}(73.6 \%) .{ }^{1} \mathrm{H}$ NMR $(\delta$ in ppm from TMS in $\left.\mathrm{CDCl}_{3}\right): 6.18(\mathrm{~s}, 1 \mathrm{H}, \mathrm{CH}=$, cis $), 5.62$ (s, $1 \mathrm{H}, \mathrm{CH}=$, trans $), 4.32-4.44\left(\mathrm{~m}, 4 \mathrm{H},-\mathrm{OCH}_{2} \mathrm{CH}_{2}-\right.$ $\left.\mathrm{CH}_{2} \mathrm{O}-\right), 2.23-2.31\left(\mathrm{~m}, 2 \mathrm{H},-\mathrm{OCH}_{2} \mathrm{CH}_{2} \mathrm{CH}_{2} \mathrm{O}-\right), 1.97$ (s, $\left.3 \mathrm{H},-\mathrm{CH}_{3}\right), 1.78-1.80\left(\mathrm{~m}, 2 \mathrm{H},-\mathrm{OCH}_{2} \mathrm{CH}_{2} \mathrm{CH}_{2} \mathrm{O}-\right.$ ); ${ }^{13} \mathrm{C}$ NMR $\left(\delta\right.$ in ppm from TMS in $\left.\mathrm{CDCl}_{3}\right): 166.86$ $(-\mathrm{C}=\mathrm{O}), 135.69\left(\mathrm{CH}_{2}=\mathrm{C}\right), 126.13\left(\mathrm{CH}_{2}=\mathrm{C}\right), 68.64$ $\left(-\mathrm{OCH}_{2} \mathrm{CH}_{2} \mathrm{CH}_{2} \mathrm{O}-\right), \quad 64.89 \quad\left(\mathrm{COOCH}_{2}-\right), 63.02$ $\left(-\mathrm{CH}_{2} \mathrm{OP}\right), 25.88\left(-\mathrm{OCH}_{2} \mathrm{CH}_{2} \mathrm{CH}_{2} \mathrm{O}-\right), 18.10\left(-\mathrm{CH}_{3}\right)$.

2-[3'-(Trimethylammonium)propylphosphoryl]ethyl Methacrylate $(T P M)$. OPREM $(6.5 \mathrm{~g}, 0.026 \mathrm{~mol})$ and $90 \mathrm{ml}$ of dry acetonitrile were placed in a $200 \mathrm{ml}$ glass pressure resistance bottle. After the bottle was cooled below $-30^{\circ} \mathrm{C}, 17.8 \mathrm{~g}(0.30 \mathrm{~mol})$ of trimethylamine were dissolved in the mixture by bubbling. The closed glass bottle was stirred at $60^{\circ} \mathrm{C}$ for $46 \mathrm{~h}$. The precipitate formed was filtered off and purified by recrystallization in acetonitrile to give white crystalline TPM. Yield $3.1 \mathrm{~g}$ $(38.5 \%) .{ }^{1} \mathrm{H}$ NMR ( $\delta$ in ppm from 3-(trimethylsilyl)-1propane-sulfonic acid, sodium salt (TMSPS) in $\mathrm{D}_{2} \mathrm{O}$ ): $6.08(\mathrm{~s}, 1 \mathrm{H}, \mathrm{CH}=$, cis $), 5.64(\mathrm{~s}, 1 \mathrm{H}, \mathrm{CH}=$, trans $), 4.26$ (br s, $2 \mathrm{H}, \mathrm{COOCH}_{2}-$ ), 4.02 (br s, $2 \mathrm{H},-\mathrm{CH}_{2} \mathrm{OP}$ ), 3.84 (q, $\left.2 \mathrm{H}, \mathrm{POCH}_{2}-\right), 3.36\left(\mathrm{t}, J=8.25 \mathrm{~Hz}, 2 \mathrm{H},-\mathrm{CH}_{2} \mathrm{~N}^{+}\right), 3.03$ (s, $\left.9 \mathrm{H},-\mathrm{N}\left(\mathrm{CH}_{3}\right)_{3}\right), 2.01$ (br s, $2 \mathrm{H}, \mathrm{PO}-\mathrm{CH}_{2} \mathrm{CH}_{2} \mathrm{CH}_{2} \mathrm{~N}^{+}$), $1.84\left(\mathrm{~s}, 3 \mathrm{H},-\mathrm{CH}_{3}\right) ;{ }^{13} \mathrm{C}$ NMR ( $\delta$ in ppm from TMSPS in $\left.\mathrm{D}_{2} \mathrm{O}\right): 170.58(-\mathrm{C}=\mathrm{O}), 136.80\left(\mathrm{CH}_{2}=\mathrm{C}\right), 128.06$ $\left(\mathrm{CH}_{2}=\mathrm{C}\right), 65.53\left(\mathrm{COOCH}_{2}-\right), 65.42\left(-\mathrm{CH}_{2} \mathrm{OP}\right), 63.34$ $\left(-\mathrm{CH}_{2} \mathrm{~N}^{+}\right), 53.94\left(-\mathrm{N}\left(\mathrm{CH}_{3}\right)_{3}\right), 24.92\left(\mathrm{PO}-\mathrm{CH}_{2} \mathrm{CH}_{2}{ }^{-}\right.$ $\left.\mathrm{CH}_{2}-\mathrm{N}^{+}\right), 18.36\left(-\mathrm{CH}_{3}\right)$.

Elemental Analysis. Found: H, 7.65\%; C, 47.96\%; N, $4.51 \%$. Calcd for $\mathrm{C}_{12} \mathrm{H}_{24} \mathrm{O}_{6} \mathrm{NP}: \mathrm{H}, 7.82 \%$; C, $46.60 \%$; $\mathrm{N}, 4.53 \%$.

\section{Other Materials}

MPC was synthesized essentially according to the method by Nakaya. ${ }^{2}$ HEMA and MMA were purified by distillation. Potassium persulfate (KPS) and 2,2'azobisisobutyronitrile (AIBN) were purified by ordinary methods. ${ }^{28}$ Tetrahydrofuran (THF) and all other solvents were purified by the method in the literature. ${ }^{29}$ Distilled water was used throughout the experimental. BSA was purchased from Sigma Chemical Co., Ltd.

\section{Polymerization Procedure}

Radical solution polymerizations of TPM were carried out in a sealed glass tube with the initiator at 60 and $80^{\circ} \mathrm{C}$. After polymerization for a given time, the solution was poured into a large amount of acetone to precipitate the polymer. The obtained polymer was purified by reprecipitation from the methanol solution to excess chloroform three times. The polymer was dried in vacuo for 2 days.

Radical copolymerizations of TPM with MMA and styrene (ST) were performed with AIBN in THF/methanol $(1 \mathrm{ml} / 1 \mathrm{ml})$ at $60^{\circ} \mathrm{C}$ in a sealed tube. After polymerization for a given time, the solution was poured into excess diethyl ether/methanol ( $4 \mathrm{vol} / 1 \mathrm{vol})$ to precipitate the polymer. The polymer obtained was dried in vacuo for 2 days. The composition of the copolymer obtained was calculated by ${ }^{1} \mathrm{H}$ NMR spectra and elemental analysis.

\section{Determination of Critical Micelle Concentration $(C M C)$}

Solutions of several concentrations $\left(1.0 \times 10^{-4}\right.$ to $1.0 \times 10^{-1} \mathrm{moll}^{-1}$ ) of TPM were prepared in distilled water saturated with pyrene. Fluorescence spectra from 352 to $500 \mathrm{~nm}$ were measured with a FP-777 Spectrofluorometer (JASCO) using a quartz cell $(1 \mathrm{~cm})$ and excitation wavelength at $342 \mathrm{~nm}$. CMC was determined from variation in $\left(I_{3} / I_{1}\right)$ of the first signal $\left(I_{1}\right)$ at $372-373 \mathrm{~nm}$ and third signal $\left(I_{3}\right)$ at $272-273 \mathrm{~nm}$, according to the method by Thomas. ${ }^{30}$

\section{Preparation of Polymer Microspheres}

Poly(TPM-co-MMA), poly(MPC-co-MMA), and PMMA microspheres were prepared by emulsifier free emulsion polymerizations. Constant amounts of MMA and TPM (or MPC) were placed into a separable round bottomed flask $(200 \mathrm{ml})$, equipped with a mechanical stirrer, condenser and $\mathrm{N}_{2}$ inlet tube. The solution was stirred at a rate of $350-450 \mathrm{rpm}$ at $70^{\circ} \mathrm{C}$ for $1 \mathrm{~h}$, and the required amount of KPS aqueous solution was added at once. After the mixture was stirred for another $48 \mathrm{~min}$ to $100 \mathrm{~min}$, it was cooled with ice bath. The solution was filtered through glass filter (1G3) to remove coarse particles and coagulated polymer. The filtrate was centrifuged, decanted, and redispersed in distilled water. This procedure was repeated three times. Using methanol in- 
stead of water, the same procedure was repeated three times. The obtained polymer microsphere was dried, and conversion was calculated from this weight of the polymer.

\section{Measurements of $\zeta$ Potentials}

$\zeta$ potentials of polymer microspheres were measured at $\mathrm{pH} 5.9$ at 0.001 of ionic strength adjusted by the addition of aq $\mathrm{HCl}$ to aq $\mathrm{NaCl}$ solution at room temperature using a Particle Electrophoresis Apparatus Model Mark II (Rank Brother Co.).

\section{Adsorption Procedure}

The amount of BSA adsorbed on polymer microsphere was determined by the Lowry method. ${ }^{31}$ The amount of BSA adsorbed was calculated from the content of free BSA in water, by measuring absorbance at $750 \mathrm{~nm}$ based on BSA by UV-VIS measurements with a Shimadzu UV-1200 spectrophotometer.

\section{Measurements}

Particle size was determined by a scanning electron microscope (SEM) with a Hitachi S-2300. The surface area of the particle was calculated using nitrogen and helium gas atmosphere with constant volume adsorption apparatus according to the BET equation. ${ }^{32,33}$

\section{RESULTS AND DISCUSSION}

\section{Synthesis of TPM}

TPM was synthesized according to Scheme 2, and identified from the ${ }^{1} \mathrm{H}$ and ${ }^{13} \mathrm{C}$ NMR spectra, as described in the experimental section, and elemental analysis. The ${ }^{31} \mathrm{P}$ NMR spectrum showed only a singlet peak assigned to P. Purified TPM showed strong deliquescence as well as MPC. Compared to the precursor of a five-membered phosphoryl compound, 2-chloro-2oxo-1,3,2-dioxaphosphorane (CODP), used in the preparation of MPC, CODPR was relatively stable to water. CODPR did not decompose even on contact with water. In the use of CODPR dry atmosphere was not always needed. Intermediate OPREM was very stable to water. Thus OPREM can be polymerized to obtain polymers bearing a six-membered ring. Synthesis and its characterization of OPREM polymers will be reported in the near future.

\section{Radical Solution Homopolymerization of TPM}

The results of radical solution homopolymerizations of TPM are summarized in Table I. The polymerizations were performed at TPM monomer concentration over CMC. When TPM concentration was less than CMC, appreciable polymers could not be obtained. TPM monomer indicated solubility in polar solvents such as water and methanol because of the possession of a phosphorylcholine analogous group at the side chain end.

Table I. Radical polymerizations of TPM

\begin{tabular}{|c|c|c|c|c|c|c|c|}
\hline \multirow{2}{*}{ Run } & Monomer & \multirow{2}{*}{$\begin{array}{c}\text { Initiator } \\
\left(\times 10^{-3} \mathrm{~mol} \mathrm{~L}^{-1}\right)\end{array}$} & \multirow{2}{*}{$\frac{\text { Polym. solvent }}{\mathrm{ml}}$} & \multirow{2}{*}{$\frac{\text { Polym. temp }}{{ }^{\circ} \mathrm{C}}$} & \multirow{2}{*}{$\frac{\text { Polym. time }}{\mathrm{h}}$} & \multirow{2}{*}{$\frac{\text { Convn. }}{\%}$} & \multirow{2}{*}{$\frac{\eta_{\mathrm{sp}} / C^{\mathrm{a}}}{\mathrm{dl} \mathrm{g}^{-1}}$} \\
\hline & $\left(\mathrm{mol} \mathrm{L}^{-1}\right)$ & & & & & & \\
\hline 2 & 0.85 & $\mathrm{~K}_{2} \mathrm{~S}_{2} \mathrm{O}_{8}(5.0)$ & $\mathrm{H}_{2} \mathrm{O}(2)$ & 80 & 0.1 & 72.1 & 0.79 \\
\hline 3 & 0.84 & $\mathrm{~K}_{2} \mathrm{~S}_{2} \mathrm{O}_{8}(5.0)$ & $\mathrm{H}_{2} \mathrm{O}(2)$ & 80 & 2 & 76.2 & 0.32 \\
\hline 4 & 0.85 & AIBN (5.0) & $\mathrm{CH}_{3} \mathrm{OH}(2)$ & 60 & 2 & 44.2 & 0.46 \\
\hline
\end{tabular}

${ }^{\text {a }}$ Measured in $\mathrm{CH}_{3} \mathrm{OH}$ at $30^{\circ} \mathrm{C}$. ${ }^{\text {b }} 2.12$ when measured in $\mathrm{H}_{2} \mathrm{O}$ at $30^{\circ} \mathrm{C}$.

Table II. Radical copolymerizations of TPM $\left(\mathrm{M}_{1}\right)$ with ST, MMA, or BMA $\left(\mathrm{M}_{2}\right)$ in a mixture of THF and $\mathrm{CH}_{3} \mathrm{OH}^{\mathrm{a}}$ at $60^{\circ} \mathrm{C}^{\mathrm{b}}$

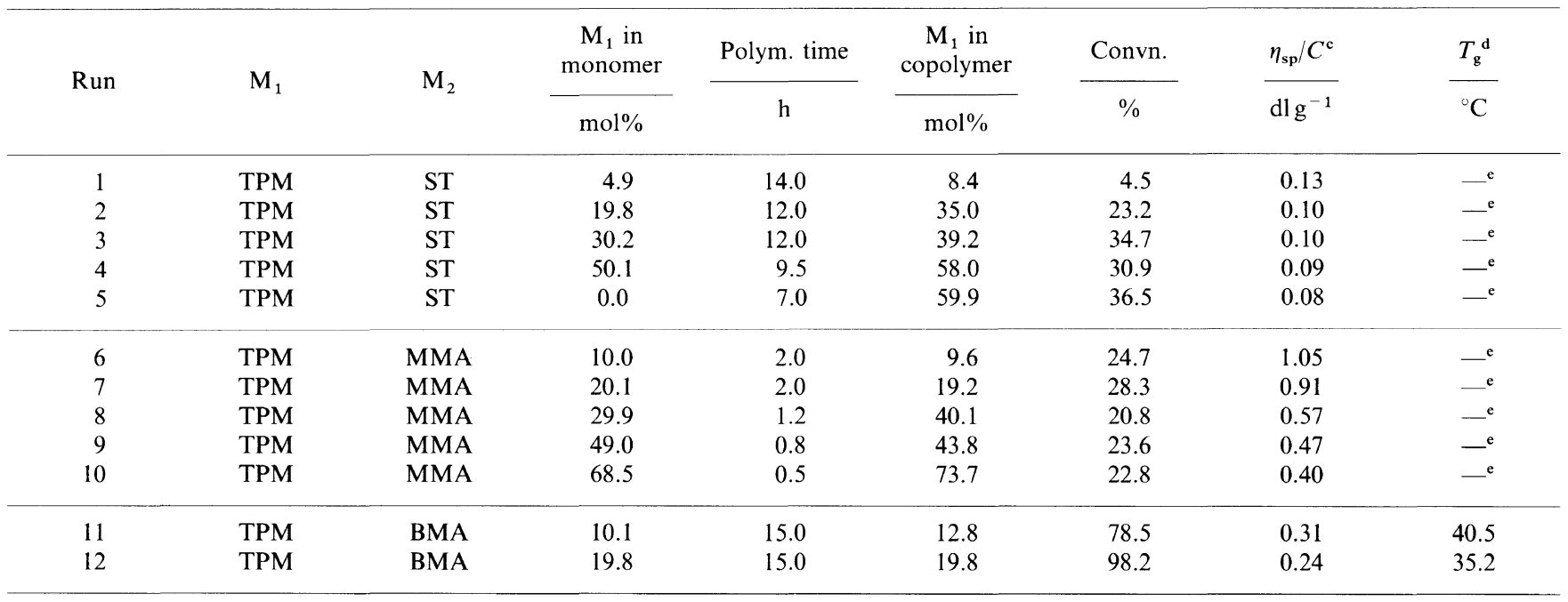

${ }^{\mathrm{a}} \mathrm{THF} / \mathrm{CH}_{3} \mathrm{OH}=1.0 \mathrm{ml} / 1.0 \mathrm{ml}$ (run $1-10,12$ ) or $\mathrm{THF} / \mathrm{CH}_{3} \mathrm{OH}=1.4 \mathrm{ml} / 0.6 \mathrm{ml}$ (run 11 ). ${ }^{\mathrm{b}}[\mathrm{AIBN}]=5.0 \times 10^{-3} \mathrm{~mol} \mathrm{~L}^{-1} ; \mathrm{M}_{1}+\mathrm{M}_{2}=0.5 \mathrm{~g}$. ${ }^{\mathrm{c}}$ Measured in $\mathrm{THF} / \mathrm{CH}_{3} \mathrm{OH}=1: 1(\mathrm{vol} \%:$ vol\%) (run $1-10)$ or $\mathrm{THF} / \mathrm{CH}_{3} \mathrm{OH}=7: 3$ (vol\%: vol\%) (run 11,12$)$ at $30^{\circ} \mathrm{C}$. ${ }^{\mathrm{d}} \mathrm{Determined} \mathrm{by} \mathrm{DSC}$. e No measurements. 
Table III. Copolymerization data

\begin{tabular}{|c|c|c|c|c|c|c|c|c|}
\hline $\mathrm{M}_{1}$ & $\mathbf{M}_{2}$ & Solvent & $\frac{\text { Temp }}{{ }^{\mathrm{C}}}$ & $r_{1}$ & $r_{2}$ & $Q_{1}$ & $e_{1}$ & Ref \\
\hline TPM & MMA & $\mathrm{THF}-\mathrm{CH}_{3} \mathrm{OH}(=1: 1)$ & 60 & 1.05 & 0.91 & 0.87 & 0.59 & This work \\
\hline TPM & ST & $\mathrm{THF}-\mathrm{CH}_{3} \mathrm{OH}(=1: 1)$ & 60 & 0.52 & 0.37 & 0.97 & 0.49 & This work \\
\hline MPC & ST & $\mathrm{CH}_{3} \mathrm{COOC}_{2} \mathrm{H}_{5}-\mathrm{CH}_{3} \mathrm{OH}(=8: 3)$ & 60 & 0.39 & 0.46 & 0.76 & 0.51 & 36 \\
\hline
\end{tabular}

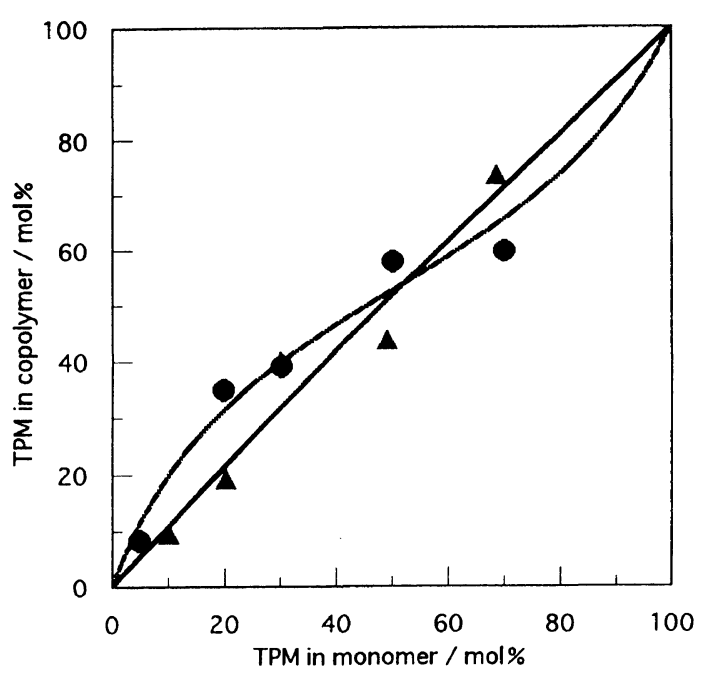

Figure 1. Copolymer-composition curves for ( $)$ TPM-ST and $(\boldsymbol{A})$ TPM-MMA systems.

All polymerizations proceeded homogeneously throughout. In the polymerization in distilled water, yields and reduced viscosities were relatively higher in spite of short polymerization time. This tendency was similar to that for MPC. ${ }^{26}$ That is, the length of a methylene unit in the phosphorylcholine group does not influence the polymerization reactivity. However, the specific rotations were very different among the polymers (run 1 to 3 ) in spite of almost the same conversion. The reason is not clear at the present time. The poly(TPM)s obtained were soluble in water and methanol, but insoluble in chloroform and THF. In addition, the polymer exhibited deliquescence because of a phosphorylcholine analogous group having hydrophilic nature as well as poly(MPC). It seems that the ordinary radical addition polymerization took place because the signals assigned to vinyl protons disappeared in the ${ }^{1} \mathrm{H}$ NMR spectrum.

\section{Radical Copolymerization of TPM with ST, MMA, or $B M A$ \\ TPM was radically copolymerized with ST, MMA, or} $\mathrm{BMA}$ in a mixture of methanol and $\mathrm{THF}$ at $60^{\circ} \mathrm{C}$. The results are summarized in Table II. All copolymerizations proceeded homogeneously throughout. Copolymer composition was calculated from ${ }^{1} \mathrm{H}$ NMR spectra and elemental analysis.

In all copolymerization systems, polymer yield increased with TPM content in the copolymer. It seems that the yield is concerned with solubility of the copolymer obtained. Reduced viscosities decreased with increase of TPM content in the copolymer. That is, molecular weight decreased with increase of the TPM content because a bulky phosphorylcholine group re-
Table IV. Solubility of TPM copolymers

\begin{tabular}{|c|c|c|c|c|c|}
\hline \multirow{2}{*}{ Run } & \multirow{2}{*}{$M_{1}$} & \multirow{2}{*}{$\mathrm{M}_{2}$} & \multirow{2}{*}{$\begin{array}{c}\begin{array}{c}\mathrm{M}_{1} \text { in } \\
\text { copolymer }\end{array} \\
\mathrm{mol} \%\end{array}$} & \multicolumn{2}{|c|}{ Solvent } \\
\hline & & & & $\mathrm{H}_{2} \mathrm{O}$ & $\mathrm{CHCl}_{3}$ \\
\hline 1 & TPM & ST & 8.4 & $x$ & 0 \\
\hline 2 & TPM & ST & 35.0 & $x$ & $\triangle$ \\
\hline 3 & TPM & ST & 39.2 & $x$ & $\bar{x}$ \\
\hline 4 & TPM & ST & 58.0 & 0 & $x$ \\
\hline 5 & TPM & ST & 59.9 & 0 & $\times$ \\
\hline 6 & TPM & MMA & 9.6 & $x$ & 0 \\
\hline 7 & TPM & MMA & 19.2 & $\triangle$ & $\triangle$ \\
\hline 8 & TPM & MMA & 40.1 & $\triangle$ & $x$ \\
\hline 9 & TPM & MMA & 43.8 & 0 & $x$ \\
\hline 10 & TPM & MMA & 73.7 & 0 & $x$ \\
\hline 11 & TPM & BMA & 12.8 & $x$ & 0 \\
\hline 12 & TPM & BMA & 19.8 & $x$ & 0 \\
\hline
\end{tabular}

$\bigcirc$, soluble; $\times$, insoluble; $\triangle$, swelling.

duced the polymerizability of TPM. Reduced viscosity for the TPM-MMA copolymers (run 6-10) and TPMBMA copolymers (run 11,12) were much higher than those for the TPM-ST copolymers (run 1-5). Glass transition temperatures were determined as $40.5^{\circ} \mathrm{C}$ and $35.2^{\circ} \mathrm{C}$ according to DSC.

Figure 1 shows copolymer-composition curves for the copolymerization of TPM $\left(\mathrm{M}_{1}\right)$ with ST $\left(\mathrm{M}_{2}\right)$, or MMA $\left(\mathrm{M}_{2}\right)$. The curve for the TPM-MMA system is equal to almost ideal copolymerization along the azeotropic line.

The monomer reactivity ratios calculated by the high conversion method reported by Kelen and co-workers, ${ }^{34}$ and Alfrey-Price ${ }^{35} Q$ and $e$ values are shown in Table III. In both systems, $r_{1}$ were little larger than $r_{2}$, which suggests that the polymerization reactivity of TPM is higher than that of $\mathrm{M}_{2}$ monomer. The copolymerization parameter for TPM was similar to those for MPC reported by Sato et al. ${ }^{36}$

Table IV shows solubility of the TPM copolymers. The copolymer consisting of the $20 \mathrm{~mol} \%$ TPM exhibited no complete solubility in chloroform and THF but swelling. Solubility increased in water but decreased in chloroform as the content of TPM increased. The copolymers containing the TPM of 19 to $40 \mathrm{~mol} \%$ swelled in water and had hydrogel structures containing much water.

\section{Molecular Aggregation of TPM in Water}

Molecular aggregation of TPM was investigated according to the fluorescence probe method of Thomas et al. ${ }^{30}$ Fluorescence spectra for pyrene were measured in distilled water at $342 \mathrm{~nm}$ excitation wavelength. Pyrene using as a fluorescence probe depicts high hydrophobic 
Table V. Emulsifier-free emulsion copolymerizations of TPM $\left(\mathrm{M}_{1}\right)$ and MPC $\left(\mathrm{M}_{1}\right)$ with MMA $\left(\mathrm{M}_{2}\right)$

\begin{tabular}{|c|c|c|c|c|c|c|c|c|c|c|c|c|}
\hline \multirow{2}{*}{ Run } & \multirow{2}{*}{$\begin{array}{c}\mathrm{M}_{1} \\
\times 10^{3}(\mathrm{~mol})\end{array}$} & \multirow{2}{*}{$\begin{array}{c}\mathrm{M}_{2} \\
\times 10^{3}(\mathrm{~mol})\end{array}$} & \multirow{2}{*}{$\begin{array}{l}\text { Initiator } \\
\times 10^{3}(\mathrm{~mol})\end{array}$} & \multirow{2}{*}{$\frac{\begin{array}{c}\text { Dispersion } \\
\text { medium }^{\mathrm{b}}\end{array}}{\mathrm{ml}}$} & \multirow{2}{*}{$\frac{\begin{array}{l}\text { Speed of } \\
\text { agitation }\end{array}}{\text { rpm }}$} & \multirow{2}{*}{$\frac{\begin{array}{c}\text { Polym. } \\
\text { temp }\end{array}}{{ }^{\circ} \mathrm{C}}$} & \multirow{2}{*}{$\frac{\begin{array}{c}\text { Polym. } \\
\text { time }\end{array}}{\min }$} & \multirow{2}{*}{$\frac{\text { Convn. }^{\mathrm{c}}}{\%}$} & \multirow{2}{*}{$\frac{\begin{array}{c}\text { Surface } \\
\text { area }^{\mathrm{d}}\end{array}}{\mathrm{m}^{2} \mathrm{~g}^{-1}}$} & \multirow{2}{*}{$\frac{\text { Diameter }^{\mathrm{e}}}{\mathrm{nm}}$} & \multirow{2}{*}{$\frac{\eta_{\mathrm{sp}} / C^{\mathrm{f}}}{\mathrm{dl} \mathrm{g}^{-1}}$} & \multirow{2}{*}{$\frac{\zeta \text {-Potential }}{\mathrm{g}}$} \\
\hline & & & & & & & & & & & & \\
\hline 1 & ТPM (1.0) & 100 & 0.10 & 100 & 450 & 70 & 48 & 46.6 & 21.62 & 321 & 11.9 & -55.3 \\
\hline 2 & TPM (1.0) & 100 & 0.30 & 100 & 350 & 70 & 30 & 41.5 & $-^{j}$ & 336 & $\ldots^{\mathbf{j}}$ & $-j$ \\
\hline 3 & TPM (1.0) & 100 & 0.10 & 100 & 350 & 70 & 60 & 63.8 & $-^{j}$ & ${ }^{j}$ & $-^{j}$ & $-^{j}$ \\
\hline 4 & MPC (1.0) & 100 & 0.40 & 100 & 450 & 70 & 55 & 59.3 & 11.00 & 356 & $4.54^{\mathrm{h}}$ & -54.1 \\
\hline 5 & None & 70 & 0.53 & 70 & 350 & 70 & 100 & 35.2 & 17.86 & 326 & $0.94^{\mathrm{i}}$ & -54.6 \\
\hline
\end{tabular}

${ }^{\mathrm{a}} \mathrm{K}_{2} \mathrm{~S}_{2} \mathrm{O}_{8} .{ }^{\mathrm{b}} \mathrm{H}_{2} \mathrm{O}$. $\quad{ }^{\mathrm{c}}$ Except coarse particles, coagulated polymer and water soluble polymer. ${ }^{\mathrm{d}}$ Calculated by BET equation. ${ }^{\mathrm{e}} \mathrm{Calculated}$ from SEM pictures. ${ }^{\mathrm{f}}$ Measured in THF at $30^{\circ} \mathrm{C}$. ${ }^{\mathrm{g}}$ Measured at pH 5.9 at r.t. ${ }^{\mathrm{h}} M_{n}=74,000 M_{w} / M_{n}=2.69 . \quad{ }^{\mathrm{i}} M_{n}=24,000 M_{w} / M_{n}=4.90 . \quad{ }^{\mathrm{j}} \mathrm{No}$ measurements.

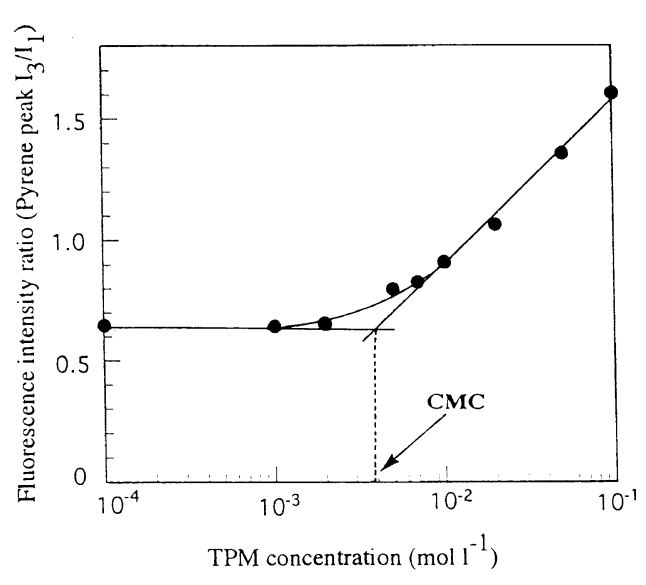

Figure 2. Fluorescence intensity ratio vs. TPM concentration in distilled water.

nature. In the TPM aqueous solution, pyrene molecules tend to aggregate with hydrophobic site of TPM to avoid hydrophilic sites of TPM, i.e., the phosphorylcholine group. Consequently, phosphorylcholine sites tend to orient toward the aqueous layer. Accordingly, TPM monomer can play a role of an emulsifier itself to form a micelle. The fluorescence signal intensity for pyrene in water, i.e., under hydrophilic atmosphere, is different from that after micelle formation, i.e., under hydrophobic atmosphere. ${ }^{30}$ That is, the fluorescence intensity of peak $I_{1}$ at $383-384 \mathrm{~nm}$ and peak $I_{3}$ at $372-373 \mathrm{~nm}$ changes. ${ }^{30}$

Figure 2 shows the relationship between fluorescence intensity $\left(I_{3} / I_{1}\right)$ and TPM concentrations in distilled water. Signal intensity $\left(I_{3} / I_{1}\right)$ remarkably changed at $3.6 \times 10^{-3} \mathrm{moll}^{-1}$, which suggests that the field for pyrene changed from hydrophilic environment to hydrophobic one at the concentration. The concentration was determined as a critical micelle concentration (CMC) of TPM in water. TPM formed micelles with comonomers having hydrophobic nature such as MMA in water over the CMC as well as MPC to obtain polymer microspheres.

\section{Preparation of Polymer Microsphere}

Table V summarizes the results of emulsifier free emulsion copolymerizations of TPM $\left(\mathrm{M}_{1}\right)$ with MMA $\left(\mathrm{M}_{2}\right)$, including data for the poly(MPC-co-MMA) and PMMA. Sugiyama et al. reported that poly(MPC-coMMA) microsphere could be obtained in best yield when the concentration of MPC was $1 \mathrm{~mol} \%$ of MMA in feed ${ }^{23}$ and that many aggregation polymers can be obtained

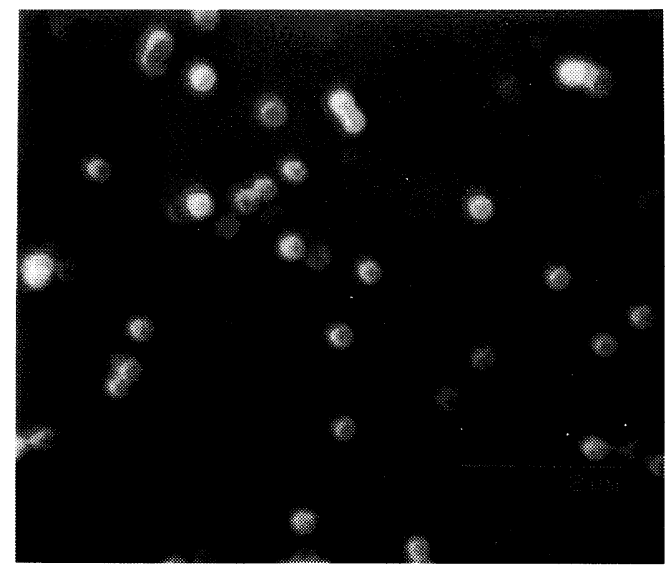

Figure 3. SEM picture of poly(TPM-co-MMA) microspheres.

under other conditions. Thus, according to the suggestion for the MPC concentration reported by Sugiyama, ${ }^{23}$ TPM concentration was determined to be $1 \mathrm{~mol} \%$ of MMA in feed. The concentration of TPM in the solution was $1 \times 10^{-2} \mathrm{moll}^{-1}$, which was over the CMC $(3.6 \times$ $10^{-3} \mathrm{moll}^{-1}$ ) of TPM in water. The conversions in Table $\mathrm{V}$ are yields of microsphere insoluble in water, which exclude crude particles, aggregating microspheres and microspheres soluble in water. The yields and reduced viscosities of the copolymers containing a phosphorylcholine and its analogous group (Table $\mathrm{V}$ run 1 to 4 ) were higher than those of PMMA, which suggests that micelles are formed in the TPM and MPC systems. The copolymerization of TPM proceeded with MMA in hydrophobic micelles prepared in the TPM aqueous solution. Thus polymerization and molecular weight of the copolymers obtained increased. The reduced viscosity $\left(11.9 \mathrm{dlg}^{-1}\right)$ of the TPM microsphere was higher than that $\left(4.54 \mathrm{dl} \mathrm{g}^{-1}\right)$ of MPC. The emulsifier free copolymerization of TPM with MMA indicated higher reactivity as well as solution polymerization, as shown in Table II.

\section{Characterization of Particles}

Surface microsphere area is shown in Table V. Figure 3 displays a typical SEM of the microsphere. The average diameter of a poly(TPM-co-MMA) particle was $321 \mathrm{~nm}$. Surface area of a poly(TPM-co-MMA) particle was $21.62 \mathrm{~m}^{2} \mathrm{~g}^{-1}$, according to the BET equation. ${ }^{33}$

\section{Adsorption of BSA onto Microspheres}

Figure 4 shows the results of adsorption of BSA onto various microspheres measuring in $\mathrm{pH} 6.6$ at $25^{\circ} \mathrm{C}$ for 


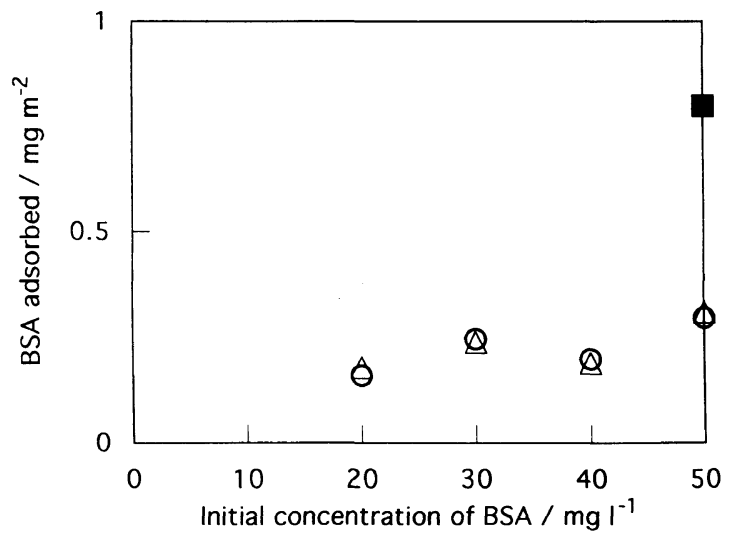

Figure 4. Adsorption of BSA onto various microspheres in the buffer solution (pH 6.6) at $25^{\circ} \mathrm{C}$ for $2 \mathrm{~h}$ : (O), poly(TPM-co-MMA); ( $\left.\mathbf{\square}\right)$, poly(MMA); $(\triangle)$, poly(MPC-co-MMA).

2 h. Poly(TPM-co-MMA) more strongly depressed adsorption of BSA than PMMA. The depression of BSA adsorption by poly(TPM-co-MMA) was similar to that by poly(MPC-co-MMA), which was the best depression of BSA adsorption reported so far. ${ }^{22}$ The structure of three methylene units between zwitter-ions could not prevent depression of BSA adsorption.

\section{CONCLUSIONS}

(1) A new methacrylate bearing a phosphorylcholine analogous moiety, TPM was synthesized, homopolymerized and copolymerized with vinyl monomers.

(2) Monomer reactivity $\left(r_{1}, r_{2}\right)$ in the copolymerizations of TPM $\left(M_{1}\right)$ and methyl methacrylate (MMA, $\mathrm{M}_{2}$ ) or styrene $\left(\mathrm{ST}, \mathrm{M}_{2}\right)$ and Alfrey-Price $Q, e$ were determined as follows:

$r_{1}=0.52, r_{2}=0.37, Q_{1}=0.97, e_{1}=0.49$ in the TPM-ST system and $r_{1}=1.05, r_{2}=0.91, Q_{1}=0.87, e_{1}=0.59$ in TPM-MMA system.

(3) CMC of TPM was determined to be $3.6 \times 10^{-3}$ mol1 $1^{-1}$ by the fluorescent probe method.

(4) Poly(TPM-co-MMA) microspheres could be prepared by emulsifier-free emulsion copolymerizations of TPM with MMA.

(5) Adsorption property of BSA on these microspheres was investigated. Poly(TPM-co-MMA) more strongly depressed adsorption of BSA than poly(MMA). The depression of BSA adsorption by poly(TPM-coMMA) was similar to that by poly(MPC-co-MMA). The structures of three methylene units between zwitter-ions could not prevent depression of BSA adsorption.

Acknowledgments. We are thankful to Mr. M. Momoi for carrying out the elemental analysis.

\section{REFERENCES}

1. B. Hupfer, H. Ringsdorf, and H. Schupp, Makromol. Chem., 182, 247 (1981).
2. T. Umeda, T. Nakaya, and M. Imoto, Makromol. Chem., Rapid Commun., 3, 457 (1982).

3. J. A. Hayward and D. Chapman, Biomaterials, 5, 135 (1984).

4. J. A. Hayward, A. A. Durrani, C. J. Shelton, D. C. Lee, and D. Chapman, Biomaterials, 7, 126 (1985).

5. Z. Foltynowicz, K. Yamaguchi, B. Czajka, and S. L. Regen, Macromolecules, 18, 1394 (1985).

6. M. Yasuzawa, T. Nakaya, and M. Imoto, J. Macromol. Sci. Chem., A23, 963 (1986).

7. A. A. Durrani, J. A. Hayward, and D. Chapman, Biomaterials, 7, 121 (1986).

8. A. Furukawa, T. Nakaya, and M. Imoto, Makromol. Chem., 187, 311 (1986).

9. A. Furukawa, H. Shoji, T. Nakaya, and M. Imoto, Makromol. Chem., 188, 265 (1986).

10. B. Hall, R. R. Bird, M. Kojima, and D. Chapman, Biomaterials, 10, 219 (1989).

11. K. Yamaguchi, S. Watanabe, and S. Nakahama, Makromol. Chem., 190, 1195 (1989).

12. D. Letourneur, C. Donzon, and Jozefowicz, J. Polym. Sci., Part A, Polym. Chem., 29, 1367 (1991).

13. C. E. Soltys, J. Bian, and M. F. Roberts, Biochemistry, 32, 9545 (1993).

14. H. Lampavski, Y-S. Lee, T. D. Sell, and D. F. O'Brian, J. Am. Chem. Soc., 115, 8096 (1993).

15. K. Ishihara, A. Fujiike, Y. Iwasaki, K. Kurita, and N. Nakabayashi, J. Polym. Sci., Part A, Polym. Chem., 34, 199 (1996).

16. K. Ishihara, T. Ueda, and N. Nakabayashi, Polym. J., 22, 355 (1990).

17. K. Ishihara, R. Aragaki, T. Ueda, A. Watanabe, and N. Nakabayashi, J. Biomed. Mater. Res., 24, 1069 (1990).

18. K. Ishihara, N. P. Ziats, B. P. Tierney, N. Nakabayashi, and J. M. Anderson, J. Biomed. Mater. Res., 25, 1397 (1991).

19. K. Ishihara, H. Oshida, Y. Endo, T. Ueda, A. Watanabe, and N. Nakabayashi, J. Biomed. Mater. Res., 26, 1543 (1992).

20. K. Ishihara, T. Tsuji, T. Kurosaki, and N. Nakabayashi, J. Biomed. Mater. Res., 28, 225 (1994).

21. Y. Iwasaki, K. Kurita, K. Ishihara, and N. Nakabayashi, $J$. Biomater. Sci., Polym. Ed., 8, 151 (1996).

22. K. Sugiyama, K. Shiraishi, K. Ohga, H. Shirahama, H. Tamai, H. Yasuda, and K. Kikukawa, Polym. J., 25, 521 (1993).

23. K. Sugiyama and H. Aoki, Polym. J., 26, 561 (1994).

24. K. Sugiyama, K. Ohga, H. Aoki, and N. Amaya, Macromol. Chem. Phys., 196, 1907 (1995).

25. J. Yu, N. M. K. Lamba, J. M. Courtney, T. L. Whateley, J. D. S. Gaylor, G. D. O. Lowe, K. Ishihara, and N. Nakabayashi, Int. J. Artif. Organs, 17, 499 (1994).

26. T. Oishi, T. Fukuda, H. Uchiyama, F. Kondou, H. Ohe, and H. Tsutsumi, Polymer, 38, 3109 (1997).

27. W. M. Lanham, U.S. Patent, 2,892,862 (1959).

28. T. Otsu and M. Kinoshita, "Koubunshigousei no Jikkenhou, Kagakudojin,” Kyoto, 1972, p 69-91.

29. J. A. Riddick, W. B. Bunger, and T. K. Sakano, "Organic Solvent," Wiley, New York, N. Y., 1986.

30. K. Kalyanasundaram and J. K. Thomas, J. Am. Chem. Soc., 99, 2039 (1977)

31. O. H. Lowry, N. J. Rosebrough, A. L. Farr, and R. J. Randall, J. Biol. Chem., 193, 265 (1951).

32. H. Hattori, A. Tata, E. Kikuchi, K. Segawa, Y. Itemidzu, "Atarashii Shokubai Kagaku," Sankyo Shuppan, Tokyo, 1988, p $147-172$.

33. S. Brunauer, P. H. Emmett, and E. Teller, J. Am. Chem. Soc., 60, 309 (1938).

34. F. Tüdös, T. Kelen, T. Foldes-Berezsnich, and B. Turcsanyi, $J$. Macromol. Sci.-Chem., A10, 1513 (1976)

35. T. Alfrey, Jr. and C. C. Price, J. Polym. Sci., 2, 101 (1947).

36. T. Sato, T. Miyoshi, M. Seno, K. Shudo, and K. Matsuyama, Polym. Prepr. Jpn., 45, 117 (1996). 